\title{
EKSPLORASI PROSES PENGOLAHAN TUMBUHAN OBAT IMUNOMODULATOR SUKU ANAK DALAM BENDAR BENGKULU
}

\author{
Fitria Lestari ${ }^{1}$ \\ Ivoni Susanti ${ }^{2}$ \\ 1,2 Program Studi Pendidikan Biologi, STKIP PGRI Lubuklinggau \\ E-mail: ${ }^{1}$ Fitrinq@gmail.com, ${ }^{2}$ ivonijoe@gmail.com
}

\begin{abstract}
Immune is one of the important systems in the body that can reduce bacteria, viruses, protozoa into the body and cause disease. Anak Dalam etnic in Bendar Bengkulu is one of the tribes in Musi Rawas Regency who need immunity to use medicinal plants. Each plant has a different processing. Therefore, this study aims to study the processing of plants that contain immunomodulators. The method used in this study is research on Anak Dalam etnic in Bendar Bengkulu. The technique of collecting observation data and interviews with the chiefs. Qualitative descriptive data analysis techniques in which the data obtained are then presented and described the most processing techniques. The results showed that the most processing by boiling. Based on research, it was concluded that each plant has a different processing to remove the compounds in it so that it requires medication.
\end{abstract}

Kata kunci: Tumbuhan Obat, Imunomodulator, Suku Anak Dalam Bendar Bengkulu

\section{PENDAHULUAN}

Imunitas merupakan suatu sistem penting dalam tubuh, jika terjadi penurunan imunitas maka tubuh akan sangat mudah terinfeksi virus, bakteri, protozoa, cacing, dan jamur parasitik (WHO, 2014). Infeksi merupakan penyakit kedua didunia dengan persentase 16,7\% setelah kardiovaskular. Jika jumlah dan fungsi sel imun berkurang, maka mikroorganisme patogen akan dengan mudah menyebabkan penyakit infeksi (Joyce, dkk., 2008).

Substansi yang dapat membantu memperbaiki fungsi sistem imun dikenal sebagai imunomodulator yang secara klinis digunakan pada pasien dengan gangguan imunitas, antara lain pada kasus keganasan, HIV/ AIDS, malnutrisi, alergi, dan lain-lain (Masihi, 2001; Kayser, dkk. 2003). Mekanisme imunomodulator, meliputi 1) mengembalikan fungsi imun yang terganggu (imunorestorasi), memperbaiki fungsi sistem imun (imunostimulasi) dan menekan respons imun (imunosupresi).

Masyarakat umumnya mengobati penyakit infeksi menggunakan obat-obat sintetis, seperti ketoprofen, aspirin, azatioprin, sitoksan, isoprinosin, levamsiol, arginin, dan lain-lain. Akan tetapi, penggunaan obat sintetis dalam jangka waktu yang panjang dapat mengakibatkan efek negatif, seperti penurunan kadar trombosit, depresi pernapasan, uritakaria, toksik terhadap hati, gangguan saluran pencernaan, dan lain-lain. Oleh karena itu, salah satu cara untuk mengurangi dampak dari obat sintetis, yaitu penggunaan tumbuhan obat.

Tumbuhan sebagai obat memiliki keunggulan seperti mudah didapatkan, 
harga murah, dan efek samping yang ditimbulkan sedikit. Alasan penggunaan tumbuhan sebagai obat, seperti mudah ditemukan di persawahan, kebun, dan pinggir jalan dan juga mudah dikembangbiakkan sendiri di rumah Pranata (2014). Tumbuhan obat biasanya diracik khusus dan ada juga biasa digunakan dalam makanan sehari-hari seperti rempah-rempah bumbu dapur (Noor \& Zen, 2015). Salah satu suku yang ada di Kabupaten Musi Rawas yang masih menggunakan tumbuhan sebagai obat adalah Suku Anak Dalam Bendar Bengkulu.

Hasil wawancara dengan kepala suku Anak Dalam Bendar Bengkulu diketahui bahwa suku ini masih menggunakan tumbuhan sebagai obat penyakit infeksi, seperti: 1) daun, akar, dan bunga bougenvile sebagai obat keputihan; 2) daun tapak dara sebagai obat leukimia; 3) daun dan bunga alamanda digunakan untuk penawar racun dan obat malaria dan lainnya. Menurut Jauhari (2012), kebiasaan Suku Anak Dalam ini tidak terlepas dari perilaku yang sudah diturunkan dari nenek moyangnya yang sangat bergantung pada alam dan meramunya. Namun, keberadaan tumbuhan yang digunakan sebagai obat oleh suku ini belum tercatat dan diidentifikasi dengan baik, hal ini terbukti dengan belum ditemukannya referensi yang membahas tentang tumbuhan obat oleh suku ini secara online maupun buku. Padahal dokumentasi pengetahuan tradisional dalam pemanfaatan tumbuhan, akan tetapi dapat juga diturunkan untuk generasi-generasi berikutnya (Hidayat \& Hardiansyah, 2016).
Oleh karena itu, penelitian ini diharapkan menjadi data awal keberadaan cara pengolahan yang digunakan oleh Suku Anak Dalam Bendar Bengkulu khususnya sebagai imunomodulator.

\section{METODE}

Penelitian ini dilaksanakan dari bulan Januari s.d September 2019 pada Suku Anak Dalam Bendar Bengkulu STL Ulu Terawas Kabupaten Musi Rawas. Pemilihan lokasi penelitian ini mempertimbangkan beberapa hal, antara lain: 1) Daerah tersebut memiliki potensi tumbuhan obat imunomodulator yang banyak. 2) Kayanya pengetahuan masyarakat akan memanfaatkan obat herbal. 3) Belum pernah dilakukan pendataan tumbuhan obat imunomodulator yang ada di daerah tersebut.

Tempat pelaksanaan juga dilakukan di Laboratorium STKIP PGRI Lubuklinggau untuk tempat mengidentifikasi tumbuhan obat imunomodulator yang didapatkan di lapangan dan dicocokkan dari hasil observasi dan wawancara.

Data yang dikumpulkan ada dua yaitu meliputi data sumber primer dan sekunder. Teknik pengumpulan data meliputi tahap:

\section{a. Tahap Observasi}

Menurut Riduwan (2007), observasi yaitu melakukan pengamatan secara langsung ke objek penelitian untuk melihat dari dekat kegiatan yang dilakukan. Observasi dilakukan pada Suku Anak Dalam Bendar Bengkulu yang berlokasi di STL Ulu Terawas Kabupaten Musi Rawas. Pada tahap ini peneliti melakukan pengamatan langsung dan menggali infomasi dari kepala suku dan masyarakat yang 
menggunakan tumbuhan sebagai obat imunomodulator dengan menggunakan lembar observasi.

\section{b. Tahap Wawancara}

Pengambilan data dilakukan mengajukan pertanyaan yang telah dipersiapkan sehingga diperoleh informasi data lisan dari responden. Metode ini dilakukan dengan mewawancarai sejumlah tokoh masyarakat terutama para sesepuh desa, tokoh adat, dukun, penjual jamu dan masyarakat setempat yang sering memanfaatkan tumbuhan obat sebagai responden yang berpedoman pada daftar pertanyaan yang dipersiapkan.

Masyarakat yang menjadi informan dipilih dengan cara purposive sampling dan snowball sampling. Informan yang dianggap ahli dalam tumbuhan obat yaitu seperti kepala suku, tokoh masyarakat, penjual jamu, dukun, dan tukang urut ditentukan dengan purposive sampling. Sedangkan masyarakat yang mengetahui tentang tumbuhan obat imunomodulator ditentukan dengan snowball sampling.

\section{Teknik Analisis Data}

Analisis data dalam penelitian ini menggunakan teknik deskriptif kualitatif dimana data yang didapat dari hasil wawancara dan observasi dikelompokkan berdasarkan temuan kemudian didukung dengan referensi yang ada.

\section{HASIL}

Hasil observasi dan wawancara yang telah dilakukan dengan kepala suku dan masyarakat diketahui bahwa cara pengolahan tumbuhan obat berpotensi imunomodulator terdiri dari 9 cara, yaitu direbus, diseduh, diperas, ditempel, tanpa diramu, diasapkan/dipanggang, diparut, dihaluskan, diparut, dan ditetes. Pengolahan terbanyak yaitu dengan cara direbus sebanyak 28 tumbuhan dengan persentase $34,56 \%$. Sedangkan yang paling sedikit dengan cara ditetes sebesar 1,23\% (Tabel 1).

\section{Tabel 1. Teknik Pengolahan Tumbuhan Obat Imunomodulator Suku Anak Dalam Bendar Bengkulu}

\begin{tabular}{|c|c|c|c|}
\hline $\begin{array}{l}\mathbf{N} \\
\mathbf{0}\end{array}$ & $\begin{array}{c}\text { Cara } \\
\text { Pengolahan }\end{array}$ & Jumlah & $\begin{array}{c}\text { Persenta } \\
\text { se }(\%)\end{array}$ \\
\hline 1 & Direbus & 28 & 34.56 \\
\hline 2 & Diseduh & 3 & 3,70 \\
\hline 3 & Diperas & 6 & 7,41 \\
\hline 4 & Ditempel & 14 & 17,28 \\
\hline 5 & Tanpa Diramu & 7 & 8,64 \\
\hline 6 & $\begin{array}{l}\text { Diasapkan/ } \\
\text { dipanggang }\end{array}$ & 7 & 8,64 \\
\hline 7 & Dihaluskan & 12 & 14,81 \\
\hline 8 & Diparut & 3 & 3,70 \\
\hline 9 & Ditetes & 1 & 1,23 \\
\hline \multicolumn{2}{|r|}{ Jumlah } & 81 & 100 \\
\hline
\end{tabular}

\section{PEMBAHASAN}

Berdasarkan hasil penelitian diketahui bahwa cara pengolahan yang banyak dilakukan oleh Suku Anak Dalam Bendar Bengkulu adalah dengan cara direbus. Tujuan merebus tumbuhan obat adalah untuk memindahkan zat-zat berkhasiat yang ada pada tumbuhan ke dalam larutan air, kemudian diminum untuk kebutuhan pengobatan (Mahendra, 2006). Cara perebusan dipercaya masyarakat dapat membunuh kuman yang ada pada tumbuhan, lebih aman dan senyawa kandungan yang ada pada tumbuhan lebih banyak keluar.

Kartika (2015) dalam Jurnal nya yang berjudul "Inventarisasi Jenis-Jenis Tumbuhan Berkhasiat Obat Di Desa 
Tanjung Baru Petai Kecamatan Tanjung Batu Kabupaten Ogan Ilir (OI) Provinsi Sumatera Selatan" menyatakan bahwan jenis tumbuhan yang ditemukan di Desa Tanjung Baru Petai Kecamatan Tanjung Batu Kabupaten Ogan Ilir Provinsi Sumatera Selatan terdiri dari 2 class, 31 ordo, 33 familia, 40 genus, dan 40 spesies. Cara pengolahan tumbuhan obat yang banyak digunakan adalah cara direbus. Hal ini didukung Tamelene, dkk (2017) bahwa etnis Tobaru di Pulau Halmahera banyak mengoleh tumbuhan obat dengan cara di rebus untuk perawatan kehamilan dan persalinan.

Pengolahan tumbuhan obat dengan cara direbus bisa mengurangi rasa hambar dan pahit dibandingkan dimakan langsung, serta dengan direbus lebih steril karena bisa membunuh kuman ataupun bakteri yang pathogen (Novianti, 2014). Proses direbus dapat mengangkat zat yang terkandung pada tumbuhan dan mempunyai reaksi yang begitu cepat bila diminum (Gunadi, 2017). Sedangkan dengan cara diiris, digosok, dijus, disangrai dan minum maupun yang lainya, proses pengolahan juga lebih lama dan zat yang terkadung didalam tumbuhan juga sedikit yang keluar sehingga proses penyembuhan bisa mengakibatkan waktu yang lebih lama. Tumbuhan obat biasa digunakan dalam makanan sehari-hari seperti rempahrempah bumbu dapur dan sayuran seperti daun Jinten, katu dan lainnya (Noor \& Zen, 2015).

Semakin besar lama waktu perebusan maka aktivitas antioksidan semakin rendah (Wicaksono, 2015). Senyawa yang terdapat dalam daun seperti daun sirsak pada suhu $60^{\circ} \mathrm{C}$ dapat menyebabkan perubahan struktur, sehingga dapat disimpulkan bahwa pemanasan yang berlebih akan menyebabkan sel terdegradasi, sehingga aktivitas antioksidan menjadi menurun. Seluruh senyawa dalam daun akan terekstrak akan keluar dan tercampur dalam larutan air setelah mencapai titik optimal akan mengalami penurunan. Disebabkan akibat proses hidrolisis selama proses ekstraksi dan pemanasan yang berlangsung terus menerus dengan $80^{\circ} \mathrm{C}$ (Oematan, 2015).

\section{KESIMPULAN}

Berdasarkan hasil penelitian dapat disimpulkan bahwa cara pengolahan tumbuhan obat sebagai imunomodulator yang digunakan oleh Suku Anak Dalam Bendar Bengkulu masih bervariasi. adanya variasi ini diharapkan dapat menjadi alternatif untuk meminimalisir penggunaan dan dampak jangka panjang dari obat kimia yang ada dipasaran.

\section{DAFTAR RUJUKAN}

Joyce, B., dan Swain. Prinsip-prinsip Sains Untuk Keperawatan. Jakarta: Erlangga. 2008.

Kayser O, K.N. Masihi, F.K. Kiderlen. 2003. Review: natural products and synthetic compounds as immunomodulators. Expret Rev Anti-infect Ther. Vol 1(2): 31-35.

Pranata, S. 2014. Herbal TOGA (Tanaman Obat Keluarga). Yogyakarta: Aksara Sukses.

Jauhari, B.V. 2012. Jejak Peradaban Suku Anak Dalam. Bangko: Lembaga Swadaya Masyarakat Kelompok Suku Anak Dalam.

Hidayat, D dan G. Hardiansyah, 2012. Studi Keanekaragaman Jenis Tumbuhan Obat di Kawasan 
IUPHHK PT. Sari Bumi Kusuma

Camp Tontang Kabupaten Sintang. Journal Biology Science, Vol 8(2): 61-68.

Mahendra, B. 2006. 13 Jenis Tanaman

Obat Ampuh. Jakarta: Penebar Swadaya.

Kartika, T. 2015. Inventarisasi Jenis-Jenis Tumbuhan Berkhasiat Obat Di Desa Tanjung Baru Petai Kecamatan Tanjung Batu Kabupaten Ogan Ilir (OI) Provinsi Sumatera Selatan. Sainmatika, 12 (1): 32-41.

Tamelene, M.N., Arini, Z.N., dan Siti, A.S.. 2017. Etnobotani Tumbuhan Obat untuk Perawatan Kehamilan dan Persalinan Etnis Tobaru di Pulau Halmahera. Jurnal Biologi dan Pembelajarannya, 4(2): 32-40.

Masihi, K.N. 2001. Fighting infection using immunomodulatory agents. Exp Opin Biol Ther. Vol 1(4): 6473.

Noor, R. \& S. Zen. 2015. Inventarisasi Tanaman Obat di Masyarakat Suku Semende Kecamatan Way Tenong Lampung Barat. Prosiding Seminar Nasional: Transformasi Nilai-nilai Islam dalam Meningkatkan SDM

$\begin{array}{lrr}\text { Bangsa } & \text { Indonesia. } & \text { Lembaga } \\ \text { Penelitian } & \text { UM } & \text { Metro. } \\ \text { ISBN.9786027413504 } & \end{array}$

Gunadi. 2017. Studi Tumbuhan Obat Pada Etnis Dayak di Desa Geranting Kecamatan Monterado Kabupaten Bengkayang. Jurnal Hutan Lestari, 5(2): 425-436.

Wicaksono. 2015. Pengaruh Karagenan dan Lama Perebusan Daun Sirsak Terhadap Mutu dan Karakteristik Jelly Drink Daun sirsak. Jurnal Pangan dan Agroindustri. 3(1): 281-291

Oematan. 2015. Pengaruh Perbedaan Suhu dan Waktu Ekstraksi Terhadap Kandungan Tanin Pada Ekstrak Daun Jambu Mete (anacurdium occidentale). Jurnal Ilmiah Mahasiswa Universitas Surabaya. 4 (2): 1-12.

World Health Organization (WHO) . 2004. The global burden of disease: 2004 update. Switzerland

Riduwan, M.B.A. 2007. Belajar Mudah Penelitian untuk Guru, Karyawan dan Peneliti Pemula. Bandung: Alfabeta. 